\title{
First Records of a Plesiosaurian (Reptilia: Sauropterygia) and an Ichthyosaur (Reptilia: Ichthyosauria) from Yukon, Canada
}

\author{
James A. Campbell ${ }^{1, *}$, Claudia J. Schröder-Adams ${ }^{1}$, James W. Haggart ${ }^{2}$, Patrick S. Drucken- \\ MILLER $^{3}$, Michael J. RYAN ${ }^{1,4}$, AND GRANT D. ZAZULA ${ }^{5}$
}

\author{
${ }^{1}$ Department of Earth Sciences, Carleton University, 1125 Colonel By Drive, Ottawa, Ontario K1S 5B6 Canada \\ ${ }^{2}$ Geological Survey of Canada, Natural Resources Canada, 1500-605 Robson Street, Vancouver, BC V6B 5J3 Canada \\ ${ }^{3}$ University of Alaska Museum and Department of Geology and Geophysics, University of Alaska Fairbanks, 907 Yukon Drive, \\ Fairbanks, Alaska 99775 USA \\ ${ }^{4}$ Department of Vertebrate Paleontology, Cleveland Museum of Natural History, 1 Wade Oval Drive, Cleveland, Ohio 44106 \\ 1767 USA \\ ${ }^{5}$ Yukon Palaeontology Program, Department of Tourism and Culture, Government of Yukon, Box 2703, Whitehorse, Yukon \\ Y1A 2C6 Canada \\ *Corresponding author; email: james.campbell@carleton.ca
}

Campbell, James, A., Claudia J. Schröder-Adams, James W. Haggart, Patrick S. Druckenmiller, Michael J. Ryan, and Grant D. Zazula. 2013. First records of a Plesiosaurian (Reptilia: Sauropterygia) and an Ichthyosaur (Reptilia: Ichthyosauria) from Yukon, Canada. Canadian Field-Naturalist 127(3): 234-239.

An isolated centrum collected ex situ from marine shales of the Lower Cretaceous (Albian) Arctic Red Formation along the Road River represents the first documented occurrence of a plesiosaurian from Yukon. This centrum represents the northernmost occurrence of plesiosaurians in the Western Interior Sea of North America prior to the establishment of the first continuous seaway (Western Interior Seaway) connecting the Boreal and Tethyan seas. Additionally, this centrum is potentially the secondoldest elasmosaurid specimen known from North America. A second centrum, collected along the Beaver River, is likely derived from the Lower Cretaceous (Lower Albian) Garbutt Formation exposed farther upstream. It represents the first report of an ichthyosaur from Yukon. Additionally, six associated ribs collected from the Arctic Red Formation along the Peel River may also belong to a marine reptile; however, poor preservation of these ribs prevents a definitive taxonomic assignment.

Key Words: plesiosaurian; elasmosaurid; ichthyosaur; marine reptile; Early Cretaceous; Albian; Western Interior Sea; Arctic Red Formation; Garbutt Formation; Yukon

\section{Introduction}

The Western Interior Seaway of North America began to form during the Early Cretaceous (Aptian to Albian), when the northern Boreal and southern Tethyan seas inundated the foreland basin east of the North American Cordillera (Kauffman 1984). Plesiosaurians are known from sediments deposited in the southwardtransgressing arm of the Boreal Sea prior to its first established connection with the Tethyan Sea in the Late Albian (Kauffman 1984; Druckenmiller and Russell 2008, 2009). The northernmost documented occurrences of plesiosaurians in this proto-seaway are from northern Alberta, in the Lower Albian Wabiskaw Member of the Clearwater Formation. These include elasmosaurids, polycotylids, and leptocleidids (Druckenmiller and Russell 2006, 2008, 2009). Plesiosaurians from younger, Campanian strata have also been found farther north along the Anderson River in the Northwest Territories (Russell 1967). Here, we present the first documented evidence of plesiosaurians and ichthyosaurs in Yukon (Figure 1). The plesiosaurian and ichthyosaur fossils reported here are of Early Cretaceous (early Middle Albian) and probable Early Cretaceous (Early Albian) age, respectively.

\section{Regional Geology}

The Albian (Lower Cretaceous) Arctic Red Formation of northeastern Yukon and the western Northwest Territories is a marine sequence composed predominantly of shale (Mountjoy and Chamney 1969; Thomson et al. 2011). The deposition of this formation represents an early incursion of the Boreal Sea into the Western Interior Basin prior to the formation of the Western Interior Seaway. This formation records deposition close to the Boreal entrance of the Western Interior Sea (Figure 2).

The Lower Albian Garbutt Formation of the Fort St. John Group, deposited during the same early incursion of the Boreal Sea, is widely distributed in the Cordilleran foothills of northern British Columbia and southern Yukon (Stott 1982; Jowett and Schröder-Adams 2005). Shales of the formation were deposited in outer shelf marine environments below storm wave base (Leckie and Potocki 1998).

\section{Results}

Systematic Palaeontology

Plesiosauria (de Blainville 1835)

Elasmosauridae indet. (Cope 1869) 


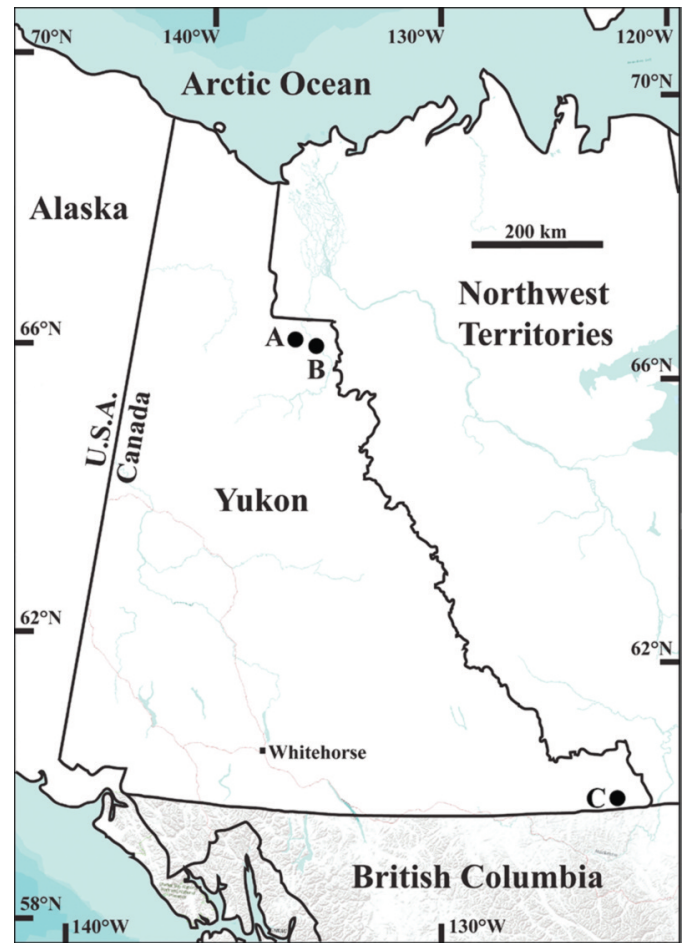

FIgURE 1. Regional map showing fossil localities (ArcGIS Desktop, Release 10, Environmental Systems Research Institute (ESRI), Redlands, Calif., modified): A, Yukon Government specimen 426.1; B, Canadian Museum of Nature specimen 40559; C, Yukon Government specimen 55.1.

\section{MATERIAL}

Yukon Government Fossil Collection 426.1: an isolated centrum.

\section{LOCALITY AND HORIZON}

Yukon Government specimen 426.1 was collected in 2010 as a loose, ex situ element by JAC from marine shales of the Arctic Red Formation exposed along the Road River (6642'30.196"N, 135¹7'52.559"W) (Figures 1 and 3). Small dark grey accumulations of silty mudstone characteristic of the locality adhered to the outer surface of the centrum (Figure 3). Additionally, an ammonite assemblage encased in a separate loose block of silty mudstone was collected near the centrum and at the same stratigraphic horizon. Both the centrum and assemblage were found near in-place bedrock. The ammonite assemblage is composed of Beudanticeras glabrum (Whiteaves 1889) and cf. Arcthoplites cf. aburense (Spath 1933; Jeletzky 1964). These taxa are characteristic of the northern Cordilleran Beudanticeras affine ammonite zone of Jeletzky (1964, 1970), of early Middle Albian age (Ogg et al. 2012).

\section{DESCRIPTION}

Yukon Government specimen 426.1 (Figure 3) is an isolated oval centrum with amphiplatyan articular surfaces. It displays moderate erosion of its surficial bone texture. Two low-relief, parallel longitudinal ridges on the dorsal surface define the lateral margins of the neural canal. The centrum lacks rib facets, a lateral longitudinal ridge, and foramina subcentralia on the ventral surface, although each of these features, if present, may have been modified by erosion. The centrum is

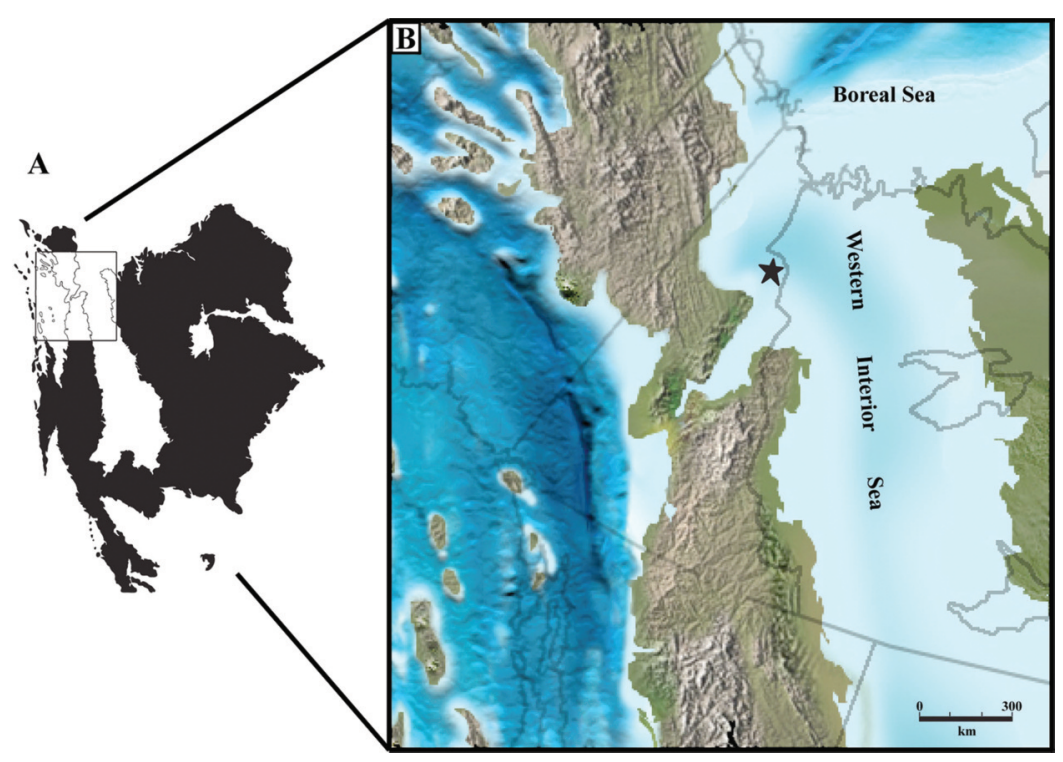

Figure 2. Palaeogeographic map, late Early Cretaceous (Middle to Late Albian) (Blakey 2012, modified): North America (A) and inset showing Boreal entrance of the Western Interior Sea (B). Star indicates site localities of Yukon Government specimen 426.1 and Canadian Museum of Nature specimen 40559. 


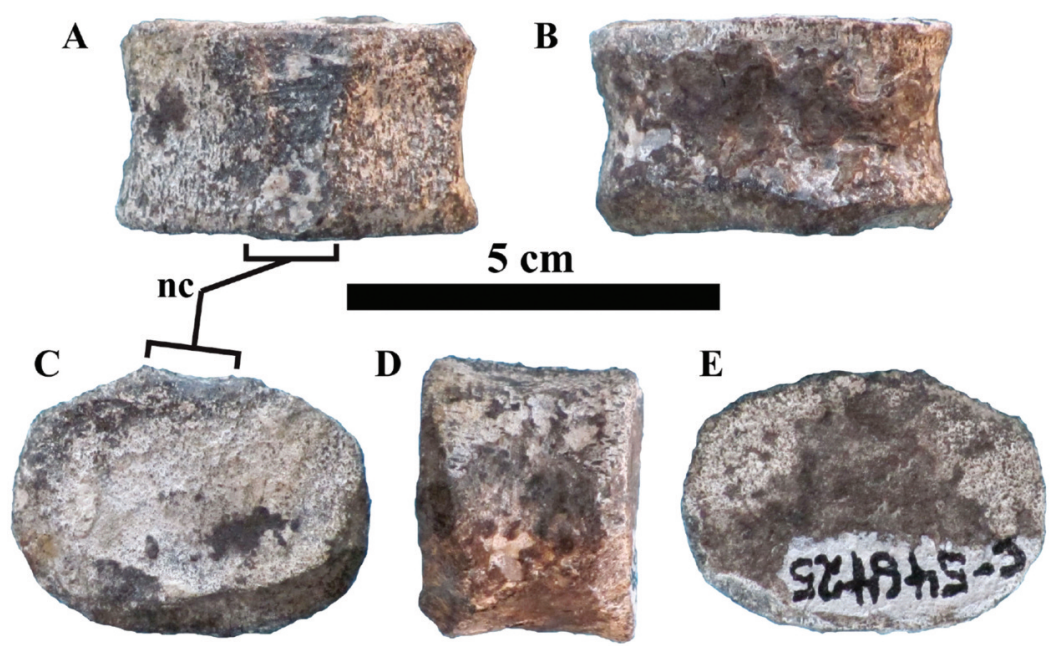

FigURE 3. Plesiosaurian vertebra (Yukon Government specimen 426.1): dorsal view (A), ventral view (B), anterior (?) view (C), lateral view (D), and posterior (?) view (E). nc = neural canal.

approximately $4.3 \mathrm{~cm}$ wide, $3.3 \mathrm{~cm}$ high, and $2.8 \mathrm{~cm}$ long.

Yukon Government specimen 426.1 is interpreted to be a dorsal centrum based on its lack of rib or chevron facets, which are typical of cervical and/or caudal centra. Its ratio aspect (broader than tall) is typical of elasmosaurids, but this ratio aspect is unknown in any short-necked plesiosaurian from this time (leptocleidids, pliosaurids, and polycotylids); therefore, it is assigned to Elasmosauridae indet., pending the discovery of more diagnostic material. Its small size and lack of a fused neurocentral suture suggest that it is likely from a juvenile individual. However, it is also possible that the neural arch was originally present but was removed by erosion.
Ichthyosauria indet. (de Blainville 1835)

MATERIAL

Yukon Government Fossil Collection 55.1: an isolated centrum.

\section{LOCALITY AND HORIZON}

Yukon Government specimen 55.1 was surfacecollected by D. MacDonald in 1998 adjacent to the Beaver River in southeastern Yukon $\left(60^{\circ} 08^{\prime} 58.1^{\prime \prime} \mathrm{N}\right.$, $\left.124^{\circ} 58^{\prime} 47.4^{\prime \prime} \mathrm{W}\right)$ (Figures 1 and 4), near an outcrop mapped as the Lower Triassic Toad Formation (Fallas and Evenchick 2006). This site corresponds to the locality of Section MWB-01-028 in MacNaughton (2002).

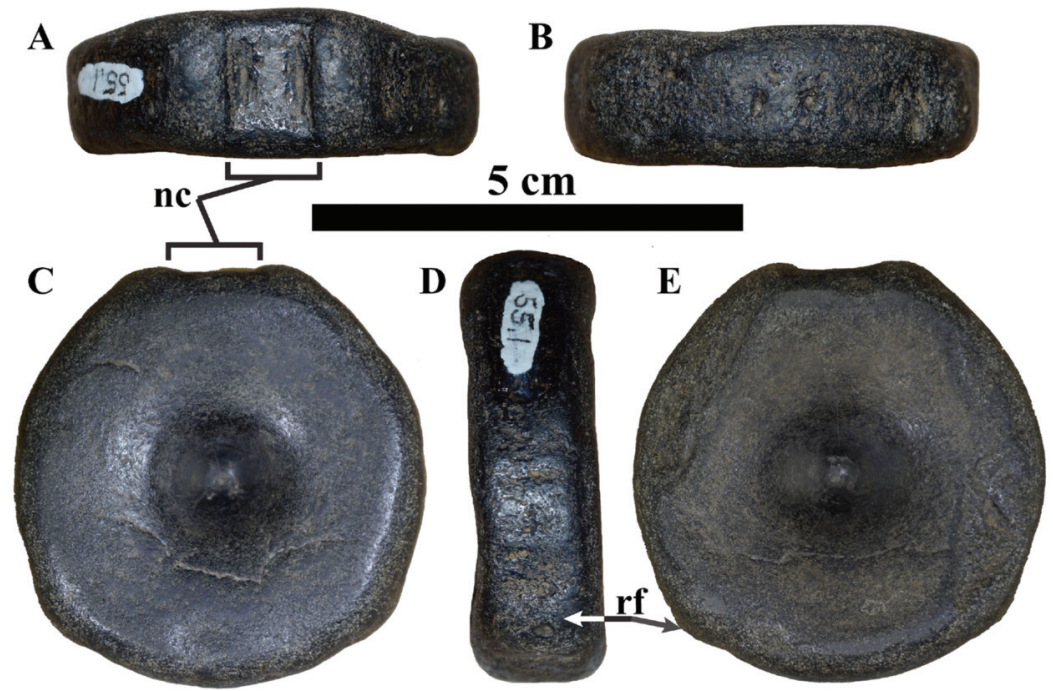

FIGURE 4. Ichthyosaur vertebra (Yukon Government specimen 55.1): dorsal view (A), ventral view (B), anterior (?) view (C), lateral view (D), and posterior (?) view (E). $\mathrm{nc}=$ neural canal; $\mathrm{rf}=$ rib facet. 


\section{DESCRIPTION}

The amphicoelous centrum is moderately weathered and polished (Figure 4). The dorsal one-third of the centrum is mediolaterally narrower than the ventral one-third in articular view. Two parallel ridges define the neural canal dorsally. A single rib facet located on the ventrolateral margin of the centrum is consistent with its referral to the posterior dorsal or caudal vertebral series. It is approximately $4.6 \mathrm{~cm}$ wide, $4.7 \mathrm{~cm}$ high, and $1.5 \mathrm{~cm}$ long.

Yukon Government specimen 55.1 is identified as ichthyosaurian, based on its overall morphology (i.e., amphicoelous with a short anteroposterior length), which closely corresponds to described Cretaceous ichthyosaurian centra of northern Canada (e.g., Maiaspondylus) (Maxwell and Caldwell 2006). The centrum is larger and anteroposteriorly shorter than the much smaller ichthyopterygians known from the Lower Triassic of northern Canada, such as Utatsusaurus (Shikama et al. 1978; Nicholls and Brinkman 1993) and Grippia (Brinkman et al. 1992). However, because the eroded centrum lacks other diagnostic characters, a more precise identification is not possible.

\section{Theory on provenance of Yukon Government specimen 55.1}

The derived morphology of Yukon Government specimen 55.1 is typical of Cretaceous ichthyosaurians. This suggests that it is unlikely to have come from the Lower Triassic Toad Formation. In the Beaver River region, the only non-Lower Triassic Mesozoic rocks that crop out up-valley of the ichthyosaur centrum collection site are Lower Cretaceous (Aptian to Albian) strata of the Fort St. John Group (Taylor and Stott 1999; Fallas et al. 2004; Fallas and Evenchick 2006; Khudoley and Fallas 2006). In ascending stratigraphic order, these units are the Chinkeh, Garbutt, and Scatter (Bulwell, Wildhorn, and Tussock members) formations (Leckie and Potocki 1998).

The Garbutt Formation has the most extensive outcrop exposure of the above units of the Fort St. John Group. This formation is the only unit that crops out along a river of significant flow - the Beaver River and, to a lesser extent, the Whitefish River. These rivers converge upstream of the collection site. The Garbutt Formation is also the closest unit to the collection site, cropping out only $4 \mathrm{~km}$ upstream of the site along the Beaver River. The lithology of this formation (shale) is indicative of a marine environment. For the above reasons, we consider the Garbutt Formation to be the most likely source of the morphologically derived ichthyosaur centrum. We also infer that this specimen was transported from these Lower Cretaceous (Lower Albian) rocks to its point of discovery either by river action or by glacial transport.

\section{Other Potential Marine Reptile Material}

MATERIAL

Canadian Museum of Nature specimen 40559: at least six partial ribs.

\section{LOCALITY AND HORIZON}

Canadian Museum of Nature specimen 40559 was collected by Eric Mountjoy in 1962, from a Lower Cretaceous interbedded marine shale and siltstone unit along the Peel River in northern Yukon (Mountjoy 1962*) (Geological Survey of Canada Locality 52716), 66 $6^{\circ} 38^{\prime} 0^{\prime \prime} \mathrm{N}, 134^{\circ} 28^{\prime} 0^{\prime \prime} \mathrm{W}$ (Figures 1 and 5). The locality is approximately $50 \mathrm{~km}$ southeast of the location of the site where Yukon Government specimen 426.1 was collected on the Road River and has been mapped as the Arctic Red Formation (Norris 1981).

\section{DESCRIPTION}

Canadian Museum of Nature specimen 40559 represents six partial, highly weathered, broken rib shafts (Figure 5). The ribs are closely associated and sub-parallel with each other, suggesting that they may have been articulated at their time of burial. Each rib shaft is slightly curved along its long axis. The longest preserved shaft is approximately $14.7 \mathrm{~cm}$ in length and $0.6 \mathrm{~cm}$ in width. As the specimen was collected from marine shales deposited approximately $100 \mathrm{~km}$ from the palaeo-coastline (Blakey 2012) (Figure 2), it is likely derived from a marine animal. Based on their size and overall morphology, it is plausible to assume that these ribs belong to a marine reptile; however, its poor preservation prevents a definitive taxonomic assignment.

\section{Palaeobiogeographic Implications of Fossil}

Material

The age of the ammonites associated with the plesiosaurian vertebra (Yukon Government specimen 426.1) corresponds to the period spanning the regression of the Hulcross (Harmon) Sea and the initial transgression of the Joli Fou Sea, which in the early Late Albian culminated in the establishment of the first continuous marine corridor between the Boreal and Tethyan seas (Caldwell et al. 1978, 1993; Kauffman et al. 1993; Obradovich 1993; Schröder-Adams and Pedersen 2003) (Figure 2).

This vertebra represents the northernmost occurrence of plesiosaurians in the Western Interior Sea of North America prior to the establishment of the first continuous seaway (Druckenmiller and Russell 2006, 2008, 2009). Ammonite evidence also suggests that Yukon Government specimen 426.1 may represent the second oldest elasmosaurid specimen from North America, after Wapuskanectes betsynichollsae from the Lower Albian Clearwater Formation of northern Alberta (Druckenmiller and Russell 2006). 


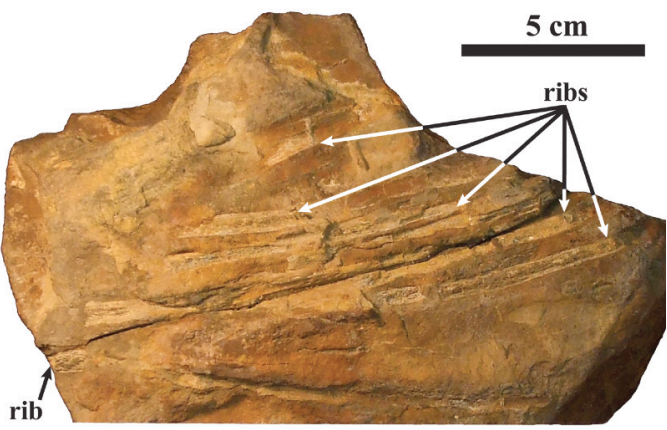

FIGURE 5. Ribs (Canadian Museum of Nature specimen 40559), likely belonging to a marine reptile (poor preservation prevents a definitive taxonomic assignment).

The plesiosaurian vertebra, as well as the ichthyosaur vertebra (Yukon Government specimen 55.1) (assuming it is Early Cretaceous in age), provides direct evidence that marine reptiles inhabited the northernmost portions of the Western Interior Sea just prior to the establishment of the Western Interior Seaway, which spanned the north-to-south length of western North America. These northern vertebrae and ribs (Canadian Museum of Nature specimen 40559) demonstrate that the Boreal Sea was likely an important entry route by which marine vertebrates moved into the seaway, and this movement ultimately resulted in a potential mixing of Boreal and Tethyan faunas.

\section{Discussion}

The Early Cretaceous (early Middle Albian) vertebra (Yukon Government specimen 426.1) and vertebra of probable Early Cretaceous (Early Albian) age (Yukon Government specimen 55.1) represent the first fossil evidence of plesiosaurians and ichthyosaurs, respectively, from the Yukon. The Albian-aged ribs (Canadian Museum of Nature specimen 40559) may also be from a marine reptile, although poor preservation precludes a definitive taxonomic assignment. Although the fossils described here cannot be identified further taxonomically, they provide new insights into the Cretaceous marine ecology of what is now Yukon. Further prospecting in the vicinity of these collection sites may reveal more taxonomically diagnostic material.

\section{Acknowledgements}

Funding for the fieldwork in 2010 was provided by a Natural Sciences and Engineering Research Council of Canada/Geo-mapping of Energy and Minerals/ ConocoPhillips Collaborative Research and Development Grant to Claudia Schröder-Adams. Logistical field support was provided by the Geo-mapping of Energy and Minerals (GEM) Program at the Geological Survey of Canada. We would like to thank Larry Lane (Geological Survey of Canada in Calgary) for fieldwork coordination, Tammy Allen (Yukon Geological Survey), and Kimberly Bell (University of Calgary) for their helpful field assistance; Michelle Coyne and Jean Dougherty (Natural Resources Canada) for their assistance in tracking down the site locality information for Canadian Museum of Nature specimen 40559; Steve Cumbaa (Canadian Museum of Nature) and Roger Benson (University of Oxford) for fruitful discussion; Kieran Shepherd (Canadian Museum of Nature) for access to the collections; Ron Blakey for providing us with a high-resolution palaeogeographic map of the late Early Cretaceous; and D. MacDonald for discovering the vertebra on the Beaver River and for making it available for scientific study and curation. Associate Editor Donald McAlpine, reviewer Graham Young, and an anonymous reviewer made constructive suggestions to improve the manuscript.

Documents Cited (marked * in text)

Mountjoy, E. W. 1962. Geological Survey of Canada field notebook, Operation Porcupine, sample 126MJ-1962. June 29th, 1962. MS.

\section{Literature Cited}

Blainville, H. M. D. de. 1835. Description de quelques espèces de reptiles de la Californie, précédée de l'analyse d'un système général d'erpétologie et d'amphibiologie. Nouvelles Annales du Muséum d'Histoire Naturelle, Paris 4: 233-296.

Blakey, R. C. 2012. Regional paleogeography. Colorado Plateau Geosystems Inc. http://cpgeosystems.com/global text2.html. (Accessed 14 December 2012).

Brinkman, D. B., X. Zhao, and E. L. Nicholls. 1992. A primitive ichthyosaur from the Lower Triassic of British Columbia, Canada. Palaeontology 35(2): 465-474.

Caldwell, W. G. E., B. R. North, C. R. Stelck, and J. H. Wall. 1978. A foraminiferal zonal scheme for the Cretaceous system in the Interior Plains of Canada. Pages 495575 in Western and Arctic Biostratigraphy. Edited by C. R. Stelck and B. D. E. Chatterton. Geological Association of Canada Special Paper 18. Geological Association of Canada, St. John's, Newfoundland and Labrador.

Caldwell, W. G. E., R. Diner, D. L. Eicher, S. P. Fowler, B. R. North, C. R. Stelck, and L. Von Holdt Wilhelm. 1993. Foraminiferal biostratigraphy of Cretaceous marine cyclothems. Pages 477-520 in Evolution of the Western Interior Basin. Edited by W. G. E. Caldwell and E. G. Kauffman. Geological Association of Canada, Special Paper 39. Geological Association of Canada, St. John's, Newfoundland and Labrador.

Cope, E. D. 1869. Synopsis of the extinct Batrachia, Reptilia and Aves of North America. Transactions of the American Philosophical Society, New Series 14: 1-252.

Druckenmiller, P. S., and A. P. Russell. 2006. A new elasmosaurid plesiosaur (Reptilia: Sauropterygia) from the Lower Cretaceous Clearwater Formation, northeastern Alberta, Canada. Paludicola 5(4): 184-199.

Druckenmiller, P. S., and A. P. Russell. 2008. Skeletal anatomy of an exceptionally complete specimen of a new genus of plesiosaur from the Early Cretaceous (early Albian) of 
northeastern Alberta, Canada. Palaeontographica 283(1-3): $1-33$.

Druckenmiller, P. S., and A. P. Russell. 2009. Earliest North American occurrence of Polycotylidae (Sauropterygia: Plesiosauria) from the Lower Cretaceous (Albian) Clearwater Formation, Alberta, Canada. Journal of Paleontology 83(6): 981-989.

Fallas, K. M., and C. A. Evenchick. 2006. Geology, Mount Merrill, Yukon Territory-British Columbia. Geological Survey of Canada Map 2091A, scale 1:50 000. Geological Survey of Canada, Ottawa, Ontario.

Fallas, K. M., L. C. Pigage, and R. B. MacNaughton. Compilers. 2004. Geology, La Biche River southwest (95C/ SW), Yukon Territory and British Columbia. Geological Survey of Canada Open File 4664, scale 1:100 000. 2 sheets. Geological Survey of Canada, Ottawa, Ontario.

Jeletzky, J. A. 1964. Illustrations of Canadian fossils. Lower Cretaceous marine index fossils of the sedimentary basins of western and Arctic Canada. Geological Survey of Canada Paper 64-11. 101 pages, 36 plates. Geological Survey of Canada, Ottawa, Ontario.

Jeletzky, J. A. 1970. Cretaceous macrofaunas. Pages 649-662 and plates 23-28 in Biochronology: Standard of Phanerozoic Time. Edited by E. W. Bamber, T. E. Bolton, M. J. Copeland, L. M. Cumming, H. Frebold, W. H. Fritz, J. A. Jeletzky, D. C. McGregor, C. J. McLaren, B. S. Norford, A. W. Norris, G. W. Sinclair, E. T. Tozer, and F. J. E. Wagner. Geological Survey of Canada, Economic Geology Report No. 1, Part B. Geological Survey of Canada, Ottawa, Ontario.

Jowett, D. M. S., and C. J. Schröder-Adams. 2005. Paleoenvironments and regional stratigraphic framework of the Middle-Upper Lepine Formation in the Liard Basin, Northern Canada. Bulletin of Canadian Petroleum Geology 53(1): 25-50.

Kauffman, E. G. 1984. Paleobiogeography and evolutionary response dynamic in the Cretaceous Western Interior Seaway of North America. Pages 273-306 in JurassicCretaceous Paleogeography of North America. Edited by G. E. G. Westermann. Geological Association of Canada Special Paper 27. Geological Association of Canada, St. John's, Newfoundland and Labrador.

Kauffman, E. G., B. B. Sageman, J. I. Kirkland, W. P. Elder, P. J. Harries, and T. Villamil. 1993. Molluscan biostratigraphy of the Cretaceous Western Interior Basin, North America. Pages 397-434 in Evolution of the Western Interior Basin. Edited by W. G. E. Caldwell and E. G. Kauffman. Geological Association of Canada Special Paper 39. Geological Association of Canada, St. John's, Newfoundland and Labrador.

Khudoley, A. K., and K. M. Fallas. Compilers. 2006. Geology, Brown Lake, Yukon Territory. Geological Survey of Canada Map 2083A, scale 1:50 000. Geological Survey of Canada, Ottawa, Ontario.

Leckie, D. A., and J. J. Potocki. 1998. Sedimentology and petrography of marine shelf sandstones of the Scatter and Garbutt formations, Liard Basin, northern Canada. Bulletin of Canadian Petroleum Geology 46(1): 36-50.

MacNaughton, R. B. 2002. Sedimentology of Triassic siliciclastic strata, Mount Martin and Mount Merrill map areas, Yukon Territory. Geological Survey of Canada, Current Research 2002-A4. 10 pages. Geological Survey of Canada, Ottawa, Ontario.
Maxwell, E. E., and M. W. Caldwell. 2006. A new genus of ichthyosaur from the Lower Cretaceous of western Canada. Palaeontology 49(5): 1043-1052.

Mountjoy, E. W., and T. P. Chamney. 1969. Lower Cretaceous (Albian) of the Yukon: stratigraphy and foraminiferal subdivisions, Snake and Peel rivers. Geological Survey of Canada Paper 68-26. 71 pages. Geological Survey of Canada, Ottawa, Ontario.

Nicholls, E. L., and D. B. Brinkman. 1993. A new specimen of Utatsusaurus (Reptilia: Ichthyosauria) from the Lower Triassic Sulphur Mountain Formation of British Columbia. Canadian Journal of Earth Sciences 30(3): 486490.

Norris, D. K. 1981. Geology, Trail River, Yukon-Northwest Territories. Geological Survey of Canada Map 1524A, scale 1:250 000. Geological Survey of Canada, Ottawa, Ontario.

Obradovich, J. D. 1993. A Cretaceous time scale. Pages 379396 in Evolution of the Western Interior Basin. Edited by W. G. E. Caldwell and E. G. Kauffman. Geological Association of Canada Special Paper 39. Geological Association of Canada, St. John's, Newfoundland and Labrador.

Ogg, J. G., L. A. Hinnov, and C. Huang. 2012. Cretaceous. Pages 793-853 in The Geologic Time Scale 2012, Volume 2. Edited by F. M. Gradstein, J. G. Ogg, A. G. Schmitz, and G. M. Ogg. Elsevier, Amsterdam, Netherlands.

Russell, D. A. 1967. Cretaceous vertebrates from the Anderson River N.W.T. Canadian Journal of Earth Sciences 4(1): 21-38.

Schröder-Adams, C. J., and P. K. Pedersen. 2003. Lithoand biofacies analyses of the Buckinghorse Formation: the Albian Western Interior Sea in northeastern British Columbia (Canada). Bulletin of Canadian Petroleum Geology 51(3): 234-252.

Shikama, T., T. Kamei, and M. Murata. 1978. Early Triassic ichthyosaur, Utatsusaurus hataii, gen. et sp. nov., from the Kitakami Massif, northeast Japan. Tohoku University Science Report, 2nd Series (Geology) 48: 77-97.

Spath, L. F. 1933. Revision of the Jurassic cephalopod fauna of Kachh (Cutch). Part VI. Memoirs of the Geological Survey of India, Palaeontologia Indica, New Series 9(2): 659-945, plates 125-130.

Stott, D. F. 1982. Lower Cretaceous Fort St. John Group and Upper Cretaceous Dunvegan Formation of the foothills and plains of Alberta, British Columbia, District of Mackenzie and Yukon Territory. Geological Survey of Canada Bulletin 328. 124 pages, 44 plates.

Taylor, G. C., and D. F. Stott. Compilers. 1999. Geology, Toad River, British Columbia. Geological Survey of Canada Map 1955A, scale 1:250 000. Geological Survey of Canada, Ottawa, Ontario.

Thomson, D., C. J. Schröder-Adams, T. Hadlari, G. Dix, and W. J. Davis. 2011. Albian to Turonian stratigraphy and palaeoenvironmental history of the northern Western Interior Sea in the Peel Plateau region, Northwest Territories, Canada. Palaeogeography, Palaeoclimatology, Palaeoecology 302(3-4): 270-300.

Whiteaves, J. F. 1889. On some Cretaceous fossils from British Columbia, the Northwest Territory and Manitoba. Geological Survey of Canada Contributions to Canadian Paleontology 1: 151-196, plates 20-24. Geological Survey of Canada, Ottawa, Ontario.

Received 13 April 2013

Accepted 24 July 2013 